\title{
Determinants of Successful Inclusive Education Practice in Lagos State Nigeria
}

\author{
Adeniyi, Samuel Olufemi ${ }^{1, *}$, Owolabi Josiah O. ${ }^{2}$ \& Olojede, Kehinde ${ }^{3}$ \\ ${ }^{1}$ Department of Educational Foundation, Faculty of Education, University of Lagos, Lagos, Nigeria \\ ${ }^{2}$ Department of Mathematics/Statistics, Federal College of Education(Technical), Akoka, Yaba, Lagos, Nigeria \\ ${ }^{3}$ Department of Curriculum Studies, Federal College of Education(Technical), Akoka, Yaba, Lagos, Nigeria \\ *Corresponding author: Department of Educational Foundation, Faculty of Education, University of Lagos, Lagos, \\ Nigeria. E-mail: safeadeniyi@yahoo.com
}

Received: January 16, 2015

Accepted: March 13, 2015 Online Published: March 27, 2015

doi:10.5430/wje.v5n2p26

URL: http://dx.doi.org/10.5430/wje.v5n2p26

\begin{abstract}
Inclusive education is a new educational philosophy and a worldwide reform strategy intended to include students with different abilities in mainstream regular schools with the aim of achieving education for all. However, there is serious concern for total inclusiveness of special needs children in Nigeria. This study therefore investigated some determinants of inclusive education practice in Nigeria. The study adopted survey research design. Samples of 227 teachers and head teachers/principals were purposively selected. Data were collected using two inventories, Materials and Manpower Inventory, and Attitudinal Inventory with reliabilities of 0.75 and 0.81 respectively. Data collected were analysed using Pearson moment correlation and multiple regression. Three research questions were answered. Materials, experience, mind-set and manpower showed significant relationship. There was joint contribution of all independent variables on dependent variable with adjusted $\mathrm{R}$ yielding of 0.998 . 'Material' was found to have contributed most significantly while 'experience' was the least in the order of magnitude. The study therefore concluded that since material, mind-set, manpower, experience and qualification jointly determined the success of inclusive education, stakeholders should ensure availability of relevant materials and as well recruit more professionals and para-professionals for the implementation of inclusive education practice in Nigeria.
\end{abstract}

Keyword: inclusive education; material; manpower; mind-set; experience; qualification

\section{Background to the Study}

The right of every child to education as proclaimed in the universal declaration of Human Right and reaffirmed by the World Declaration on Education for All in 1990 could be considered as the right step towards building a society where everybody, not minding the degree of variance, will feel accepted. However, throughout the world, children with disabilities and many others who experience difficulties in learning are often marginalised within or, indeed, even sometimes excluded from school systems (Ainscow \& Haile-Giorgis, 1998). Across the world, there are many reasons why children do not attend school; these include high level of mobility, social conflict, child labour and exploitation, poverty, gender and disability. These factors contribute in varying degrees to high rate of illiteracy and poverty index in emerging economies like Nigeria.

Inclusive Education (IE), a new educational philosophy, is a worldwide reform strategy intended to include students with different abilities in mainstream regular schools (Ahmed, Sharma \& Deppeler, 2012). In this new arrangement, school curriculums, teaching methods, organisation and resources are expected to be adapted to ensure that all learners, irrespective of their ability can successfully participate in the regular classroom activities without any serious discomfort. This new agenda was informed by World Conference on Special Needs Education held in Salamanca, Spain in 1994 which basically provided the standard rules on the equalization of opportunities for persons with disabilities. The concept of inclusive education is based on the principles that all children regardless of ability or disability have a basic right to be educated alongside their peers in their local schools (UNESCO, 1994). The new trend is aimed at removing social prejudice and alienation that have been hitherto meted on special need children within and 
outside the classroom. According to Mitchell (1999), inclusive education policies enable everyone to be accorded equal status regardless of the level of functioning or other personal characteristics that are associated with human beings, such as disabilities or in other cases, those children who are gifted and talented.

Inclusive is a global trend that involves the idea of making education accessible to all children (Bryant, Smith \& Bryant, 2008) and evidences from past research studies suggest that success of implementing effective inclusive education is predicated on many factors. Forlin (2001) identified lack of knowledge, skills and attitudes as greatest barriers to inclusive education practices. Some other variables such as mind set, teachers qualifications and experience, materials, manpower, policy practice, support from school and government and coordination have been identified as major predictors of inclusive education practice universally.

Research evidences have revealed that the success of implementation of inclusive education is contingent on teachers' positive attitude towards inclusive education (Avramidis \& Kalyva, 2007; Jordan, Schwartz \& McGhie-Richmond, 2009; Rakap \& Kaczmarek, 2010). Highlighting the importance of teachers' positive attitude, Ross-Hill (2009) posited that inclusive education cannot be implemented unless the primary stakeholders support the idea. The mind set as presented in the attitudes of teacher may be influenced by a myriad of factors (Avramidis, Bayliss \& Burden, 2000). For example, Sharma, Forlin \& Loreman (2008) and Avissar, Reiter \& Leyse (2003) found that younger teachers have more positive attitudes than older teachers, while Avramidis, Bayliss and Burden (2000) reported that age was related to the attitude of the teachers. However, despite the general acceptance and positive attitude as revealed by many research works towards inclusive education, some studies revealed that teacher do not seem to be ready for it (Semmel, Abnernathy, Baterea \& Lesar, 1991).

Furthermore, the length of teaching experience has been found to be a predicting variable of Inclusive. Study by Sharma (2001) exploring the attitude and concern of 310 primary school principals and 484 teachers in New Delhi regarding the Inclusive of students with special needs into regular school programme found that the best predictors of teachers attitude towards Inclusive were their length of teaching experience. While Cornoldi, Terreni \& Scruggs et al (1998) found that teachers with fewer years of teaching experience were more positive toward Inclusive than those with longer years, Avramidis et al (2000) did not find such relationship in their study.

Some other variables have also been found to have more consistent relationship with the success of Inclusive education practice. For instance, Avramidis \& Kalyva (2007) and Koutrouba, Vamvakari \& Steliou (2006) found relationship in length of training and attitude to Inclusive. The study by Parasaram (2006) revealed that educational qualifications could predict inclusive education practice. Mitchell and Desai (2005) also reported lack of resources such as special teachers and para-professional staff, non-availability of appropriate instructional material, lack of funding and training as major impediment to success of inclusive educational practice. Related studies by Ammah \& Hodge (2005) and Koh \& Robertson (2003) also reported consistently that inadequate resources and materials and lack of support from government may serve as major barriers to the implementation of inclusive education. Also, the study conducted by Laimuilee, Tracey, Barker, Fan and Yeung (2014) on what predicts teachers' acceptance of students with special educational needs in kindergarten reported all 275 participants indicating sense of self-efficacy as the strongest predictor of all the factors under investigation. It must be noted that self-efficacy influences mind set and attitude towards performing a particular task. The implication is that this particular variable can make or mar the implementation of inclusive education in Nigeria.

In spite of government's Inclusive policy, there are still many out-of-school special needs students roaming the streets of urban and local communities while the ones enrolled do not appear to be benefiting from the purpose of the policy, thus robbing both categories of their fundamental human right to education.

Going by myriads of factors militating against the success of inclusive education globally, it is highly expedient to investigate some determining variables of inclusive education with particular reference to Nigeria in her efforts to achieve the Millennium Development Goals.

\section{Research Questions}

1. What type of relationship exists among independent variables (mind-set, material, manpower, experience and qualification) and Inclusive Education Practice?

2. To what extent, when combined will the independent variables (mind-set, material, manpower, experience and qualification) determine the success of Inclusive Education Practice?

3. To what extent will each of the independent variables (mind-set, material, manpower, experience and qualification) determine the success of Inclusive Education Practice? 


\section{Method}

\subsection{Research Design}

This study adopted survey research design of ex-post facto in which the study only investigated existing variables without any manipulation.

\subsection{Population}

The population for the study comprised teachers and administrators in various inclusive centres in Lagos metropolis.

\subsection{Sample}

The sample comprised 180 classroom teachers and 47 head teachers directly involved in inclusive education programme purposively selected from various Inclusive centres in Lagos metropolis.

\subsection{Instrument}

Two instruments were used to collect data on inclusive education practice in Lagos State. The first instrument was Materials and Manpower Inventory with reliability of 0.75 , while the second instrument was Attitudinal Inventory that measured the mind-set towards Inclusive with reliability coefficient of 0.81 . Material and manpower inventory consisted of four sections namely A, B, C and D. Section A was on demographic data, Section B was on funding; Section $\mathrm{C}$ was on manpower development while Section D was on materials/resources. The attitudinal scale was divided into 2 parts namely: the demographic data of the respondents and attitudinal questionnaire constructed in four Likert scale i.e. Strongly Agree, Agree, Disagree and Strongly Disagree.

\subsection{Data Collection}

The questionnaires were distributed among the participants through pre-service teachers who personally visited each school to carry out their professional school observation. The responses were thereafter collected through the same pre-service teachers for analysis.

\subsection{Data Analysis}

The data collected were collated, coded and analysed using Pearson product moment correlation and multiple regression.

\section{Results}

This section presents the results of findings. The presentation follows the order in which the research questions were presented. The level of significance was set at $\mathrm{p}<0.05$.

Research Question One: What type of relationship exists among independent variables (mind-set, material, manpower, experience and qualification) and Inclusive Education Practice?

Table 1 presents the inter-correlation matrix of the correlation coefficients of the independent variables (mind-set, material, manpower, experience and qualification) and Inclusive Education Practice.

Table 1. Inter correlation Matrix of Independent and Dependent Variables

\begin{tabular}{lllllll}
\hline Variable & Mind-set & Material & Manpower & Experience & Qualification & $\begin{array}{l}\text { Inclusive } \\
\text { Education } \\
\text { Practice }\end{array}$ \\
\hline Mind-set & 1.000 & & & & \\
Material & $-0.196^{*}$ & 1.000 & & & \\
Manpower & 0.040 & $-0.428^{*}$ & 1.000 & & \\
Experience & $0.255^{*}$ & $0.228^{*}$ & 0.093 & 1.000 & & \\
Qualification & $-0.294^{*}$ & 0.011 & 0.140 & $-0.359^{*}$ & 1.000 & \\
Inclusive & $-0.187^{*}$ & $0.998^{*}$ & $-0.445^{*}$ & $0.229^{*}$ & 0.004 & 1.000 \\
Education Practice & & & & & & \\
\hline
\end{tabular}

From Table 1, it can be observed that in some, the relationships are positive and statistically significant at $\mathrm{p}<.05$. For example, the relationship between Inclusive Education Practice and material as well as Inclusive Education Practice and experience is high and statistically significant. The relationship between Inclusive Education Practice and 
experience is low but statistically significant. The above relationships show that the more materials there are for inclusive education practice the higher the success of Inclusive Education Practice. Similarly, the more the number of years of experience in teaching, the higher the Inclusive Education Practice. The table also shows that in some, the relationship is negative and also statistically significant. For example, the relationship between mind-set and Inclusive Education Practice as well the one between manpower and Inclusive Education Practice are both negative and statistically significant. This means that higher score in mind-set and experience does not necessarily mean that the real practice of Inclusive Education will be high. The relationship between qualification and Inclusive Education Practice is negative and statistically insignificant.

Research Question Two: To what extent when combined will the independent variables (mind-set, material, manpower, experience and qualification) determine the success of Inclusive Education Practice?

Table 2. Multiple Regression of the Predictor Variables (mind-set, material, manpower, experience and qualification) on Inclusive Education Practice

\begin{tabular}{ll}
\hline Parameter & Value \\
\hline Multiple Regression (R) & 0.999 \\
R - Square & 0.998 \\
Adjusted R - square & 0.998 \\
Std. Error of Estimate & 0.210 \\
\hline
\end{tabular}

Predictors: (Constant), mind-set, material, manpower, experience and qualification.

Table 2 above presents the multiple regression of the predictor variables on Inclusive Education Practice. The multiple regression correlation coefficient $(\mathrm{R})$ shows the linear relationship between the five predictor variables (mind-set, material, manpower, experience and qualification) and Inclusive Education Practice (0.999). The adjusted R square value is 0.998 . This implies that the variation in the Inclusive Education Practice accounted for by the stated predictor variables is $99.8 \%$

Table 3. Multiple Regression ANOVA

\begin{tabular}{|c|c|c|c|c|c|}
\hline Model & $\begin{array}{l}\text { Sum } \\
\text { squares }\end{array}$ & of $\mathrm{Df}$ & Mean square & $\mathbf{F}$ & Sig. \\
\hline Regression & 2865.149 & 5 & 573.030 & 13048.464 & $0.000^{\mathrm{a}}$ \\
\hline Reside & 6.851 & 156 & 0.044 & & \\
\hline Total & 2872.000 & 161 & & & \\
\hline
\end{tabular}

a. Predictors: (Constant), mind-set, material, manpower, experience and qualification.

b. Dependent variable: Inclusive Education Practice

Table 3, above shows the Multiple Regression ANOVA of the predictor variables on the Inclusive Education Practice. Further verification using multiple regression ANOVA however produced F-ratio $=13048.464, \mathrm{p}<0.05$. This implies that there is a significant linear relationship between the above stated predictor variables and Inclusive Education Practice.

Research Question Three: To what extent will each of the independent variables (mind-set, material, manpower, experience and qualification) determine Inclusive Education Practice?

Table 4. Coefficients Indicating Relative Effects of the Predictor Variables on the Inclusive Education Practice

\begin{tabular}{lllllll}
\hline & \multicolumn{2}{l}{ Unstandardized coefficients } & \multicolumn{2}{l}{ Standardized coefficient } & & \\
\cline { 2 - 7 } Model & B & Std. Error & Beta & T & Sig. & Remark \\
\hline Constant & -0.325 & 0.140 & & -2.310 & 0.022 & S \\
Mind-set & 0.005 & 0.002 & 0.011 & 2.526 & 0.013 & S \\
Material & 1.000 & 0.004 & 0.995 & 222.731 & 0.000 & S \\
Manpower & -0.114 & 0.037 & -0.014 & -3.124 & 0.002 & S \\
Experience & -0.001 & 0.002 & -0.001 & -0.267 & 0.790 & N.S \\
Qualification & 0.019 & 0.015 & 0.006 & 1.267 & 0.207 & N.S \\
\hline
\end{tabular}
a. Dependent variable: Inclusive Education Practice

S: Significant at 0.05 alpha levels. 
N.S: Not significant at 0.05 alpha levels.

Table 4 above shows the $\mathrm{r}$

Table 4 above shows the relative effects of the predictor variables on the Inclusive Education Practice. Material contributed most and directly to the Inclusive Education Practice $(B=0.995 ; t=222.731 ; p<0.05)$. The contributions of other predictor variables to the Inclusive Education Practice are: Manpower $(B=-0.014 ; t=-3.124 ; p<0.05)$, mind-set $(\mathrm{B}=0.011 ; \mathrm{t}=2.526 ; \mathrm{p}<0.05)$, Qualification $(\mathrm{B}=0.006 ; \mathrm{t}=1.267 ; \mathrm{p}>0.05)$, and Experience $(\mathrm{B}=-0.001 ; \mathrm{t}$ $=-0.267 ; \mathrm{p}>0.05)$. This implies that mind-set, material and manpower have significant relative effect on Inclusive Education Practice. Material has the highest and positive relative effect on Inclusive Education Practice.

\section{Discussion}

The result of Research Question One revealed significant relationship among some independent variables (mind-set, materials, manpower and experience) and inclusive education practice. The statistical significant relationship of the independent variables and dependent variable is an indication that before inclusive education will succeed, the mind-set of those that are directly involved in the implementation and practice of inclusive education must be favourably disposed to it, the needed materials must be available and put in place; adequate personnel (manpower) with required experience and expertise must be employed for the implementation and practice of Inclusive in Nigeria. The outcome of this study is in line with Avramidi \& Norwich (2002) and Mastropieri \& Scruggs (2000) who posited that successful implementation of inclusive education is largely dependent on the positive attitude of teachers (mind-set), Sharma (2001) who found that success of Inclusive is hinged on the length of teaching experience and contact with students with special needs availability of resources in form of instructional materials, professional and para-professional staff and funding.

The result of Research Question Two revealed joint effect of independent variables on dependent variable. The above result further demonstrated a strong link between the independent variable and dependent variable of the study. This implies that mind-set, materials, manpower, experience and qualification will jointly contribute significantly to the success of Inclusive education. The joint effect revealed in the result corroborated the finding of Lee, Tracey, Barker, Fan \& Yeung (2014) that reported joint contribution of teacher knowledge which can be equivalent to the factor of mind-set, efficacy in teaching in inclusive setting and government initiative as determining the acceptance of student with special educational needs of kindergarten.

The finding of the Research Question Three revealed that materials, manpower and mind-set contributed significantly nevertheless, materials have the highest contribution. By implication, availability of materials in all inclusive centres will enhance the success and advocacy of inclusive education in Nigeria. This finding corroborated the study by Ahmed, Sharma and Deppeler (2012) that found that the most significant factor affecting inclusive education is the perceived school support. And it is evident that perceived school support dwells significantly on availability of materials that will aid human resources to be effective.

\section{Conclusion}

To conclude, this research provides evidence of the importance of some variables determining the success of inclusive education practice. Materials, manpower, mindset, experience and qualification of teachers were variables identified to have significantly related to the success of inclusive education because of their joint determinant index as revealed by regression analysis Nevertheless availability of materials was identified to possess the highest potential to success and failure of inclusive practices in Nigeria.

It can therefore be summarized that:

- Materials and teaching experience had positive relationship with Inclusive Education Practice;

- Mind-set and manpower had negative relationship with Inclusive Education Practice;

- The five predictor variables (mind-set, material, manpower, experience and qualification) jointly accounted for $99.8 \%$ of the variation in Inclusive Education Practice;

- The relative contributions of material and manpower on Inclusive Education Practice are significant. This implies that they contributed directly to Inclusive Education Practice. Materials contributed most to the Inclusive Education Practice. 


\section{Recommendations}

In view of the significant evidences of the influence of materials, manpower, mind-set, experience and qualification on the practice of inclusive education, it is recommended that:

- Materials needed and necessary for the smooth operation of inclusive education should be made available for teachers and administrators. This should be made possible through partnership between government and non-governmental organisations.

- More professionals and para-professionals should be trained and recruited for the implementation of inclusive education.

- Also, on the job training should be given to professionals in the education of people with special needs so as to update their knowledge on the current issues.

- More publicity and advocacy campaign should be done by both government and non-governmental organisation on the plight of people with special needs and the need to include them in the mainstreaming of the society.

\section{References}

Ahmmed, M., Sharma, U., \& Deppeler, J. (2012). Variables affecting teachers' attitudes towards inclusive education in Bangladesh. Journal of Research in Special Education Needs, 12(3), 132-140. http://dx.doi.org/10.1111/j.1471-3802.2011.01226.x

Ainscow, M., \& Haile-Giorgis, M. (1998). The Education of Children with Special Needs: Barriers and Opportunities in Central and Eastern Europe. Innocenti occasional paper. Economic and Social Policy Series 67 UNICEF.

Ammah, J., \& Hodge, S. (2005). Secondary physical education teachers belief and practices in teaching students with severe disabilities: A descriptive analysis. The High School Journal, 89(2), 40-54. http://dx.doi.org/10.1353/hsj.2005.0019

Avissar, G., Reiter, S., \& Leysar, Y. (2003). Principals' views and practices regarding inclusion: The case of Israeli elementary school principals. European Journal of Special Needs Education, 18(3), 355-369. http://dx.doi.org/10.1080/0885625032000120233

Avramidis, E., \& Kalyva, E. (2007). The influence of teaching experience and professional development on Greek teachers' attitudes towards inclusion. European Journal of Special Needs Education, 22(4), 367-389. http://dx.doi.org/10.1080/08856250701649989

Avramidis, E., \& Norwich, B. (2002). Teachers' attitude towards integration/inclusion: a review of literature. European Journal of Special Needs Education, 17(2), 129-147. http://dx.doi.org/10.1080/08856250210129056

Avramidis, E., Bayliss, P., \& Burden, R. (2000). Student teachers' attitudes towards the inclusion of children with special educational needs in the ordinary school. Teaching and Teacher Education, 16, 277-293. http://dx.doi.org/10.1016/S0742-051X(99)00062-1

Bryant, D.P., Smith, D.D., \& Bryant, B.R. (2008). Teaching students with special needs in inclusive classroom. Boston, MA: Pearson Education, Inc.

Cornoldi, C., Terreni, A., Shruggs, T., \& Mastropies, M (1998). Teacher attitudes in Italy after twenty years of inclusion. Remedial and Special Education, 19, 155-135. http://dx.doi.org/10.1177/074193259801900605

Forlin, C. (2001). Inclusion: Identifying potential stressors for regular class teachers. Educational Research, 43(3), 235-245. http://dx.doi.org/10.1080/00131880110081017

Jordan, A., Schwartz, E., \& McGhie-Richmond, D. (2009). Preparing teachers for inclusive classroom. Teaching and Teacher Education, 25(4), 535-542. http://dx.doi.org/10.1016/j.tate.2009.02.010

Koh, M.S., \& Robertson, J.S. (2003). School reform model and special education. Education and Urban Society, 35(4), 421-442. http://dx.doi.org/10.1177/0013124503255495

Koutrouba, K., Vamvakari, M., \& Steliou, M. (2006). Factors correlated with teachers' attitude towards the inclusion of students with special educational needs in Cyprus. European Journal of Special Needs Education, 21(1), 381-394. http://dx.doi.org/10.1080/08856250600956162 
Lee, F.L.M., Tracey, D., Barker, K., Fan, J.C.M., \& Yeung, A.S. (2014). What predicts teachers' acceptance of students with special educational needs in kindergarten. Australian Journal of Educational and Development Psychology, 14, 60-70.

Mastropieri, M.A., \& Scruggs, T.E. (2000). The inclusive classroom strategies for effective instruction. Upper Saddles River, NJ: Merrill.

Michell, D. (1999). Inclusive school project: Creating inclusive school. University of Walkathon, Hamilton.

Mitchell, D., \& Desai, I. (2005). Diverse socio-cultural contexts for inclusive education in Asia. In D. Mitchell (Ed.), Contextualising inclusive education: Evaluating old and new international perspectives. Routledge, Oxfordshire.

Parasuram, K. (2006). Variables that affect teachers attitudes disability and inclusive education in Mumbai, India. Disability and Society, 21(3), 231-242. http://dx.doi.org/10.1080/09687590600617352

Rakap, S., \& Kaczmarek, L. (2010). Teachers' attitudes towards inclusion in Turkey. European Journal of Special Needs Education, 25(1), 59-75. http://dx.doi.org/10.1080/08856250903450848

Ross-Hill, R. (2009). Teacher attitudes towards inclusion practices and special needs students. Journal of Research in Special Education Needs, 9(3), 188-198. http://dx.doi.org/10.1111/j.1471-3802.2009.01135.x

Semmel, M., Abnernathy, T., Butera, G., \& Lesar, S. (1991). Teacher perceptions of the regular education initiative. Exceptional Children, 58, 9-12.

Sharma, U. (2001). The attitudes and concerns of school principles and teachers regarding the integration of students with disabilities into regular schools in Delhi, India. Unpublished doctoral dissertation, University of Melbourne, Melbourne.

Sharma, U., Forlin, C., \& Loreman, T. (2008). Impact of training on pre-service teachers' attitudes and concerns about inclusive education and sentiment about persons with disability. Disability and Society, 23(7), 73-85. http://dx.doi.org/10.1080/09687590802469271

UNESCO (1994). The Salamanca Statement and Frame Work for Action on Special Needs Education. Paris: UNESCO. 